\title{
DEADLOCK IN A CLOSE CORPORATION: A SUGGESTION FOR PROTECTING A DISSIDENT, CO-EQUAL SHAREHOLDER
}

While the courts and legislatures have devised concepts and guidelines for the publicly held corporation, the unique nature of the close corporation' has produced problems untouched by, or unsuited for, those principles. ${ }^{2}$ The close corporation is frequently used by businessmen who seek to derive the advantages of doing business in the corporate form while nonetheless clinging to the benefits of a partnership. ${ }^{3}$ Ownership and management usually coalesce ${ }^{4}$ with the share-

1. Israels, The Close Corporation and the Law, 33 CoRnell L.Q. 488, 491 (1948) notes "that no satisfactory all-purpose definition of a close corporation appears even to have been worked out." For a compilation of the various definitions adopted by the courts, commentators and legislatures, see 1 F. O'NEAL, Close Corporations $\$ 1.02$ (1971). In his treatise, Professor Rohrlich adopts the following definition ". . . the 'close corporation' [is a corporation] wherein all the outstanding stock (there being no publicly held securities of any other class) is owned by the persons (or members of their immediate families) who are active in the management and conduct of the business." $\mathrm{C}$. RohrLich, ORGANIzING CORPORATE AND OTHER BUSINESS ENTERPRISES $\S 4.19$, at 125 (4th ed. 1967). It is Rohrlich's definition which best defines the business entity envisioned in this Note.

THE FOLLOWING HEREINAFTER CITATIONS ARE USED IN THIS NOTE:

F. O'Neal, Cl.ose Corporations (1971) [hereinafter cited as O'Neal];

C. Rohr1.ICH, ORganizing Corporate and OTHer Business ENTERPRises (4th ed. 1967) [hereinafter cited as ROHRLiCH];

Latty, The Close Corporation and the New North Carolina Business Corporation Act, 34 N.C.L. REv. 432 (1956) [hereinafter cited as Latty].

2. Dean O'Neal notcs in his treatise that "[m]any corporate concepts and principles (undoubtedly created with public-issue corporations primarily in mind) are ill-adapted to close corporations." I O'NEAL. $\$ 1.13$, at 50 . Recognition of the unique problems arising in close eorporations has led several state legislatures to adopt either provisions in addition to their general corporate statutes specifically designed to meet the needs of close corporations or separate, integrated close corporation statutes. As examples of the former, see N.Y. Bus. CORP. LAW 620(a)-(g) (McKinney Supp. 1970); N.C. GEN. STAT. $\$ 55-73,55-125(a)$ (1965). A complete listing of the latter includes DEL. CODE ANN. tit. 8, 341-356 (Supp. 1971); FLA. Stat. ANN. $\$ 608.70-77$ (Supp. 1972); Md. ANN. Code art. 23, \$\$ 100-11 (Supp. 1971). See generally 1 O'NeaL § 1.14b; Hall, The New Maryland Close Corporation Law, 27 MD. L. Rev. 341 (1967); Comment, Comparison of the Close Corporation Statutes of Delaware, Florida and New York, 23 U. Miani L. Rev. 515 (1969).

Arguments have been advanced that inclusion of special provisions covering close corporations are more desirable than the passage of separate, integrated statutes. See generally Latty 455-57.

3. Commentators acknowledge this to be one of the primary goals of businessmen forming close corporations. I O'NEAL 1.07-.08; Cary, How Illinois Corporations May Enjoy Partnership Advantages: Planning for the Closely Held Firm, 48 Nw. U.L. REv. 427 (1953). Latty 438.

4. Unlike the typical shareholder in a publicly held corporation, who may be simply an investor or a speculator and cares nothing for the responsibilities of management, 
holders expecting to derive much, if not all, of their income in the form of salaries for managerial services rendered the corporation. Viewing themselves as "partners", the shareholders often conduct the affairs of the business with little adherence to the technical requisites of corporate decision-making. ${ }^{5}$ In spite of these marked differences, the legislative and judicial reaction to the resolution of close corporation conflicts has only slowly evolved from the traditional publicly held corporation approach $;^{6}$ as a result, inequities have arisen for which the law offers remedies which are, at best, inadequate.

The problem of "deadlock"-an impasse in corporate decisional processes-exemplifies an area where the law now affords methods of resolution which are largely unsatisfactory for the close corporation. ${ }^{7}$ Although providing that disputes arising among shareholders or directors of a corporation must be settled by the principle of majority rule, the typical state statute also allows shareholders to establish corporations whose charters or by-laws permit: (1) the even division of voting shares and board membership between opposing factions; or (2) the vesting of veto powers in minority shareholders; or (3) the setting of high voting requirements for shareholder or director action. ${ }^{8}$ As a result of a shareholders' agreement embodying such provisions, the possibility of corporate deadlock is greatly enhanced. ${ }^{9}$

the shareholder in a close corporation is a co-owner of the business and wants the privileges and powers that go with ownership. His participation in that particular corporation is often his principal or sole source of income. As a matter of fact, providing employment for himself may have been the principal reason why he participated in organizing the corporation. 1 O'NEAL $\S 1.07$, at 21 .

See also RoHrLICH 125.

5. Owners of small "family" corporations, or "incorporated partnerships" are notoriously negligent in observing the legal requirements and formalities of doing business in the corporate form. Often they are little interested in such things as minutes, meetings and resolutions, and know nothing about such legal rules as "interested directors" and "corporate opportunity"- until the day of reckoning comes, when the "partnership" breaks up in dispute or creditors decide to assert their claims. Acts done informally and in complete good faith are then tested against strict legal requirements that the parties knew nothing about or ignored. An unhappy education results. Prentice Hall, Lawyers Weekly Report: Corporations News (Jan. 24, 1955), reprinted in Latty 453.

6. I O'Neal § 1.13, at 50-51. See, e.g., Note, Some Specific Needs of the Close Corporation Not Met Under the Minnesota Business Corporation Act: Suggestions for Statutory Relief. 50 Minn. L. Rev. 1008 (1970).

7. For a discussion of the rationale suggesting that the presently available solutions for corporate deadlock are inadequate, see notes 25-39 infra and accompanying text.

8. For a discussion of these control arrangements, see 1 O'NeaL $\$ 4.01-5.39$.

9. The possibility of deadlock led some courts to refuse to enforce shareholder agreements 
The adverse consequences of corporate deadlock-for example, obstruction of even routine business matters, deleterious effects on corporate borrowing, and incessant litigation ${ }^{10}$-would perhaps be less severe were it not for an increasing willingness among courts to ascribe to the officers of close corporations powers which exceed those enjoyed by their publicly held counterparts. While the same broad principles of corporate and agency law theoretically determine the powers of officers in both close and publicly held corporations, the coalescence of ownership and management in the close corporation has led many courts to allow the officers of a close corporation to exercise powers more extensive than those ordinarily allowed the management of publicly held corporations. Analytically, these greater powers are more closely analogous to those possessed by general partners than to the powers recognized under the principles of traditional corporate law. " Under general partnership theory, each partner has authority to bind the partnership as to any matter within

embodying control arrangements such as high vote requirements for corporate action. See, e.g., Benintendi v. Kenton Hotel, 294 N.Y. 112, 60 N.E.2d 829 (1945), in which the court refused to enforce a by-law requiring unanimous vote for director action. The court stated that such a by-law

is, almost as a matter of law, unworkable and unenforcible for the reason given by the

Court of King's Bench in Dr. Hascard v. Dr. Somany, 1 Freeman 504, in 1693: "prima

facie in all acts done by a corporation, the major number must bind the lesser, or else

diffcrences could never be determined." Id. at 119,60 N.E.2d at 831 .

Of course, the draftsmen of an agreement embodying deadlock-enhancing provisions can easily include provisions to become effective upon the occurrence of deadlock. Such provision could require that disputes arising among equally divided directors and shareholders be submitted to arbitration. For a discussion of the merits of including an arbitration clause in the shareholders' agreement, see O'Neal, Resolving Disputes in Closely Held Corporations: IntraInstitutional Arbitration, 67 HARv. L. REv. 786 (1954); Note, Mandatory Arbitration as a Remedy for Intra-Close Corporate Disputes, 56 VA. L. REv. 271 (1970); Note, Arbitration as a Means of Settling Disputes Within Close Corporations, 63 Colum. L. Rev. 267 (1963). See note 60 infra for additional deadlock resolution techniques.

10. 2 O'Neal $\S 9.02$, at 4. See, e.g., Stott Realty Co. v. Orloff, 262 Mich. 375, 376, 247 N.W. 698, 699 (1933); Nashville Packet Co. v. Neville, 144 Tenn. 698, 699, 235 S.W. 64, 65 (1921); Becker \& Beckcr, Practical Suggestions for Financing a Business Enterprise, $112 \mathrm{~J}$. Accountancy 42, 45 (Dec. 1961).

11. Jaffe v. Chicago Wärehouse Lumber Co., 4 IIl. App. 2d 415, 124 N.E.2d 618 (1954) (close corporation's president has power to bind the corporation to a contract to pay the company's sales manager a bonus equal to twenty-five percent of the company's net profits); Hartford v. Massachusetts Bowling Alleys, 229 Mass. 30, 118 N.E. 188 (1918) (treasurer given power to employ manager for firm's business for period of one year); Barkin Const. Co. v. Goodman, 221 N.Y. 156, 116 N.E. 770 (1917) (secretary has power to bind the company to a contract providing that the rents from the company's property would be held by another as security for a loan); Haff v. Long Island Fuel Corp., 233 App. Div. 117, 251 N.Y. Supp. 67 (2d Dep't 1931) (where other directors and shareholders in a close corporation have acquiesced 
the ordinary scope of the firm's business; ${ }^{12}$ however, under corporate theory, the corporation is the principal and the corporate officers merely agents. ${ }^{13}$ Appointment to a corporate office carries with it no inherent authority to act for the corporation; ${ }^{14}$ therefore, corporate officers must derive whatever authority they have as agents from either express delegation in the corporation's charter, by-laws and resolutions of the board of directors, or from implied delegation by

in exclusive control by company's general manager, then that officer had authority to execute promissory note without formal director authorization). The courts have seldom articulated a difference in the rules governing officers' powers in close and publicly held corporations, yet they appear

in fact to have often cut through the technical legal form of close corporations to reaci the results that would be reached if the enterprises were conducted as partnerships. In other words, the courts frequently, and perhaps usually, recognize in officers of a close corporation the same powers that are possessed by partners in a firm under the general rule of partnership law which makes each partner an agent of the firm for the purposes of its business and empowers each partner to bind the firm by acts apparently carried on to further the usual business of the partnership. 2 O'NEAL $\$ 8.05$, at 23 (footnotcs omitted).

But see Goldenberg v. Vartell Broadcasting Corp., 47 Misc. 2d 105, 262 N.Y.S.2d 274 (Sup. Ct. 1965) (absent express authority, president did not have power to bind the firm to an employment contract providing for the issuance of corporate stock as partial compensation to the employee); N.A. Berwin \& Co. v. Hewitt Realty Co., 199 App. Div. 453, 191 N.Y.S. 817 (Ist Dep't 1922), affd mem., 235 N.Y. 608, 139 N.E. 754 (1923).

12. Every partner is an agent of the partnership for the purpose of its business, and the act of every partner . . . for apparently carrying on in the usual way the business of the partnership of which he is a member binds the partnership . . . . UNIFORM PARTNERSHIP ACT (U.L.A.) $§ 9(1)$ (West 1969).

The authority conferred by Section $9(1)$ of the Aet is not dependent upon express or apparent authority. Rather Section $9(1)$ gives a partner inherent authority to bind thc firm-authority which arises solely from the agency relationship. The Restatement (Second) of Agency states:

Inherent agency power is a term used in the restatement of this subject to indicate the power of an agent which is derived not from authority, apparent authority or estoppel, but solely from the agency relation and exists for the protection of persons harmed by or dealing with a servant or other agent. ResTATEMENT (SECOND) OF AGENCY $\S 8$, at 36 (1958).

13. H. Ballantine, Corporations $\S 49$, at 137 (rev. ed. 1946). For a detailed analysis of the powers of corporate officers, see 2 W. FleTCHER, CYCLOPEDIA CORPORATIONS $\$ 265-785$ (perm. ed. 1931).

14. See, e.g., Corporation of Amer. v. Harris, 5 Cal. App. 2d 452, 43 P.2d 307 (Dist. Ct. App. 1935); Black v. Harrison Home Co., 155 Cal. 121, 99 P. 494 (1909); Craven v. Gazza, 36 Misc. 2d 493, 232 N.Y.S.2d 896 (Sup. Ct. 1962). The view that corporate office carries with it no inherent authority has been widely acknowledged by commentators. See BaLLANTINE, supra note 13, at $\$ 49$; Annot., 34 A.L.R.2d 290, 291 (1954). But see Twyeffort v. Unexcelled Mfg. Co., 263 N.Y. 6, 9, 188 N.E. 138, 139 (1933); Harding v. Morgan Lithograph Co., 247 N.Y. 332, 338, 160 N.E. 388, 390 (1928); 2 FLETCHER, supra note 13, at $\S 558$; Note, Inherent Power as a Basis of a Corporate Officer's Authority to Contract, 57 Colum. L. REv. 868 (1957). 
the acquiescence of the directors or shareholders in a course of conduct ${ }^{15}$ or assumption of authority. ${ }^{16}$ Nonetheless, in recognizing a fundamental similarity between close corporate officers and general partners, many courts have cut through the technical form of the close corporate structure to treat their problems in a manner more consonant with partnership law than that of the otherwise applicable corporate principles. The ascription of extraordinary partnership powers to officers of close corporations, when coupled with the legislative and judicial encouragement of deadlock-causing devices, increases the likelihood of usurpation of corporate control by one of the opposing shareholder factions in the event of deadlock. If allowed to go unchecked, this usurpation of control can endanger the investment and livelihood of the excluded shareholder. ${ }^{17}$

\section{Corporate law Principles Applicable to Director and ShaReHolder DEADLOCK}

The occurrence of deadlock among equally powerful shareholders and directors raises difficult conceptual problems in any attempt to define the powers of officers in close corporations. For example, abscnt express authority, can action by less than a majority of directors bind an officer in the exercise of his powers on behalf of the corporation? The courts have failed to give clear answers to this question; those decisions which have dealt with the issue, however, have considered only the narrower question of the power of an officer

15. See, e.g., Joy v. Ditto, Inc., 356 Ill. 348, 190 N.E. 67I (1934) (alternative holding); $f$. Martin v. Wegg, 110 U.S. 7 (1884). "A corporation may be bound by its custom of doing business. It may be bound by acquiescence; it may be bound by accepting and retaining the fruits of a transaction and in other ways without any action of its Board of Directors." First Trust Co. v. Miller, 160 Wis. 336, 337, 151 N.W. 813, 814 (1915) (emphasis added).

16. See Joseph Greenspon's Sons Iron \& Steel Co. v. Pecos Valley Gas Co,, 34 Del. 567, 572,156 A. 350,352 (1931). "Where officers of a corporation surrender to the president the management and control of its affairs, and permit him to exercise unrestrained authority for a long period of time, the corporation may be liable for his acts." Allen v. France Packing Co., 170 Pa. Super. 632, 635, 90 A.2d 289, 29 I (1952).

17. Although not technically a deadlock case, Gonseth v. K \& K Oil Co., 439 S.W.2d I8 (Mo. App. 1969) provides an excellent example of the damage which might befall a shareholder who thinks he has bargained for equal control. In Gonseth, the court held that the plaintiff, who had been an equal owner with the defendant in a partnership business that they had transferred to a corporation, was not defrauded when the corporation issued 24 shares to the plaintiff, 24 shares to the defendant and 2 shares to an attorney who voted with the defendant to increase defendant's salary and to terminate the plaintiffs salary. For a discussion of "freezeout" techniques generally, see F. O'Neal and J. Derwin, Expulsion or OpPression of Business Associates: "SqueEze-Outs" in Small ENTERPRises 3.01-5.14 (1961). 
to institute or defend litigation. 18

One line of authority would allow officers to initiate an action whenever necessary to prevent irreparable injury to the interests of the shareholders ${ }^{19}$ or the corporation itself. ${ }^{20}$ These decisions are premised on the concept that, in an emergency, some person should be empowered to act in order to protect the corporation's interests. This line of cases supports the proposition that prohibition by less than a majority cannot prevent an officer from acting, if his action is essential to protect the corporation. An opposite view, however, has been taken by courts ${ }^{21}$ which were hesitant to deprive participants in a close corporation of the veto powers for which they bargained. Those courts have denied officers authority to initiate or defend litigation in the corporation's name when the directorate is deadlocked. ${ }^{22}$ Noting that the statutory norm provides that the business of a corporation shall be managed by its board of directors, courts adopting this restrictive view have argued that endowing officers with power to initiate or defend litigation would effectively amend the statute to read that "the corporation shall be managed by its board of directors except in the case of deadlock when it shall be managed by any director who happens to be president."'23 This second line of cases supports the proposition that prohibition by less than a majority is sufficient to deny an officer authority to act in the name of the corporation.

Both lines of authority provide concepts which could be useful in furnishing a remedy for the most common deadlock situation-that is, when a shareholder-officer representing one faction takes an ac-

18. 2 O'NEAL $\S 8.06$.

19. Regal Cleaners \& Dyers, Inc. v. Merlis, 274 F. 915 (2d Cir. 1921).

20. See, e.g., Regal Cleaners \& Dyers, Inc. v. Merlis, 274 F. 915 (2d Cir. 1921); Lydia E. Pinkham Medicine Co. v. Gove, 298 Mass. 59, 9 N.E.2d 573 (1937); Elblum Holding Corp. v. Mintz, 120 N.J.L. 604, I A.2d 204 (Sup. Ct. I938); Durfee \& Canning v. Canning, 78 R.I، 385,82 A.2d 615 (195I).

21. Fanchon \& Marco, Inc. v. Paramount Pictures, Inc., I07 F. Supp. 532 (S.D.N.Y. I952), rev'd on other grounds, 202 F.2d 73I (2d Cir. 1953); Seeland Inv. Corp. v. Emprise, Inc., 190 Cal. App. 2d 305, 12 Cal. Rptr. 153 (Dist. Ct. App. 1961); Kelly v. Citizen's Fin. Co., 306 Mass. 531, 28 N.E.2d 1005 (1940); Sterling Indus., Inc. v. Ball Bearing Pen Corp., 298 N.Y. 483, 84 N.E.2d 790 (1949).

22. See Application of Paloma Frocks, Inc., 1 App. Div. 2d 640, 152 N.Y.S.2d 652, 654 (1st Dep't 1956), rev'd sub nom. Paloma Frocks, Inc. v. Shamokin Sportswear Corp., 3 N.Y.2d 572, I47 N.E.2d 779, I70 N.Y.S.2d 509 (I958).

23. Sterling Indus., Inc. v. Ball Bearing Pen Corp., 298 N.Y. 483, 84 N.E.2d 790, 794 (1949) (court's emphasis). 
tion over the objection of a dissenting, equally-powerful second faction. Obviously, the latter line of cases denies the existence of any implied authority in an officer to act in the face of deadlock; the former, "emergency"24 line of cases likewise lends support to the position of the dissenting faction, except where it can be shown that the corporation is threatened by immediate, irreparable injury.

What remedies are available to a dissenting group to attack such action by a director-officer? Perhaps the remedy most widely used by dissident shareholders excluded from corporate management due to the usurpation of control by a director-officer is dissolution of the corporation. Although the corporate entity once occupied an almost sacrosanct position in the eyes of the legislatures and the courts, ${ }^{25}$ modern dissolution-for-deadlock statutes have removed many of the hindrances which hampered the efforts of dissident shareholders seeking dissolution..$^{26}$ However, the threshold question is whether dissolution is an appropriate resolution..$^{27}$ Winding-up a close corporation is a drastic remedy which will deny the shareholder-officers the opportunity to participate in an enterprise which has likely provided participants with their primary source of income. Depending on local eco-

24. Ostensibly, the courts accepting the "emergency" argument, for example, would allow a shareholder-officer to hire an employee if the officer could prove that circumstances threatened the continued operation of the business. Such extraordinary circumstances might arise if both shareholders-officers were incapacitated by illness and the corporation did not have an employee capable of operating the business.

25. See Israels, The Sacred Cow of Corporate Existence: Problems of Deadlock and Dissolution, 19 U. CHI. L. REv. 778 (I952).

26. See, e.g., Del. Code ANn. tit. 8, $\$ 355$ (Supp. 1970); MD. ANN. COdE art. 23, $\S$ 104(a)(3) (Supp. 1971); N.Y. Bus. CoRP. LAw $\S 1002$ (McKinney 1963); N.C. GeN. STAT. $\S 55-125(\mathrm{a})(3)$ (1965); PA. STAT. tit. I5, $\S$ I386 (Supp. 1969). For a discussion of these and other dissolution-for-deadlock statutes, see 2 O'NEAL $\$ 9.28-.29$; RoHRLICH $\$ 4.28$; J. Tingle, The Stockholder's Remedy of CoRporate Dissolution (I959); Howe, Corporate Divorce: Deadlock in the Close Corporation, 22 Bus. LAw. 469 (1967); Israels, supra note 25.

27. Courts have been reluctant to dissolve concerns which arc being operated profitably because of the adverse effect of dissolution on the corporation's creditors and employees. Although largely unarticulated, the courts' concern seems to be protection of the "public's interest." But see Fulk, Corporation Statutes: 1956-1966, 1966 Duke L.J. 875, at 952 (reluctance to order dissolution is based upon the recognition that a "formerly viable concern" might be revived if the deadlock could be broken). In addition, other courts have recognized the potential for abuse of the "dissolution-for-deadlock" statutes in situations where one or more shareholders attempt to use dissolution as a technique for squeezing-out dissidents. See, e.g., Kavanaugh v. Kavanaugh Knitting Co., 226 N.Y. 185, 123 N.E. I48 (1919) (two of three equal shareholders voted for dissolution of a corporation so that they could acquire its assets and operate the business without being encumbered with the dissident); O'NEAL \& DERwIN, supra note 17 , at $\S 4.09$. 
nomic conditions, a court-appointed receiver ${ }^{28}$ may be unable to find a buyer willing to purchase the enterprise as a going concern at a reasonable price. Failure to find such a buyer will necessitate the piecemeal selling of the corporation's assets, a disposition which ordinarily results in the realization of an amount substantially less than if the business were sold as a going concern.

Prior to the formulation of the modern dissolution-for-deadlock statutes, many courts were willing to afford dissident shareholders remedies short of dissolution when an opposing faction abused or usurped corporate control. ${ }^{29}$ If the alleged wrongdoing was not systematic or continuous, ${ }^{30}$ the courts have provided redress by ordering an accounting, ${ }^{31}$ by setting aside and cancelling wrongful acts, ${ }^{32}$ by injunction ${ }^{33}$ or mandamus ${ }^{34}$ to prevent future wrongs, or by some combination of these remedies..$^{35}$ The commentators, however, have underscored the general ineffectiveness of such remedies, ${ }^{36}$ noting the threat they pose to the essential harmonious relationship between shareholders of the close corporation. ${ }^{37}$ Bitter litigation between fac-

28. Under most dissolution-for-deadlock statutes there is a provision giving the court power to appoint a liquidating receiver. See, e.g., AlASKa STAT. $\$ 10.05 .558$ (I962); ILL. ANN. STAT. ch. 32, § 157.87 (Smith-Hurd 1954). See also Model Business Corporation Act $\S 98$ (1971).

29. See Hornstein, A Remedy for Corporate Abuse-Judicial Power to Wind Up a Corporation at the Suit of a Minority Stockholder, 49 CoLUM. L. REv. 220, 236 (1940).

30. Systematic or continuous abuse of corporate power has been uniformly held to be grounds for dissolution. In fact, the opinions indicate that dissolution is the only remedy for such abuse. In re Collins-Doan Co., 3 N.J. 382, 70 A.2d 159 (1949) (where one of two equal shareholders has usurped control and excluded the other shareholder over a period of ten years, "there is no alternative remedy. Redress for the corporate omissions [failure to pay dividends on stock held by excluded shareholder] may be had only by dissolution." Id. at 396, 70 A.2d at 166); Gidwitz v. Lanzit Corrugated Box Co., 20 IIl. 2d 208, 170 N.E.2d 131 (I960) (dissolution the only answer for ten years of exclusive control). See Sellman v. German Union Fire Ins. Co., 184 F. 977,979 (C.C.D. Del. 1909); Kahan v. Alaska Junk Co., 111 Wash. 39, 47, 189 P. 262,265 (1920).

31. Enterprise Printing \& Pub. Co. v. Craig, 195 Ind. 302, 144 N.E. 542 (1924).

32. See Sellman v. German Union Fire Ins. Co., 184 F. 977, 979 (C.C.D. Del. 1909).

33. Kahan v. Alaska Junk Co., 111 Wash. 39, 189 P. 262 (1920).

34. Thwing v. McDonald, 134 Minn. 148, 158 N.W. 820 (1916).

35. Id. (accounting, injunctions, mandamus, and removal of officer and director, held adequate relief for the time being); Laurel Springs Land Co. v. Fougeray, 50 N.J. Eq. 756, 26 A. 886 (1893), rev'g, 50 N.J. Eq. 185, 24 A. 499 (Ch. 1892) (accounting, setting aside improper transactions, mandamus, and order to directors to declare dividends of all net earnings not needed for legitimate purposes of the corporation, held adequate relief). See Hornstein, supra note 29 , at 236 n.117.

36. See, e.g., Hornstein, supra note 29 , at 236-37.

37. A close corporation is no less susceptible to deadlock than a partnership; furthermore, the ultimate success of both rests upon the unarticulated premise that the parties have confid- 
tions necessarily undermines that relationship. ${ }^{38}$

The apparent inability of these remedies to afford dissident shareholders a meaningful method to redress usurpation of control by an opposing faction suggests that it would be fruitful to look beyond these ordinary corporate principles. Because the courts have implicitly recognized, in officers of close corporations, authority analogous to that possessed by members of partnerships, ${ }^{39}$ an examination of the principles applied in the resolution of disagreements in a twomember partnership might be helpful.

\section{Rights of the Dissident in a Two-Member Partnership}

The authority of a partner to bind his firm, of course, is a matter subject to prior agreement among the partners, ${ }^{40}$ in the absence of agreement, however, the Uniform Partnership Act ${ }^{41}$ provides that "[e]very partner is an agent of the partnership for the purpose of its business, and the act of every partner . . . for apparently carrying on in the usual way the business of the partnership of which he is a member binds the partnership . . . ."42 In the event of dispute among partners over matters which are within the ordinary scope of the partnership business, the Act provides for majority rule; ${ }^{43}$ however, the Act does not expressly address itself to disagreements arising in a two-member partnership. The absence of a statutory resolution crystalizes the conceptual problem: under agency theory, what is the effect of a dissent from the exercise of the existing authority, possessed by each general partner, to bind the firm in matters within the

ence in and will cooperate with one anothcr. In the absence of reasonable prospects for such a harmonious relationship, it seems unlikely that a partnership, and more clearly, a close corporation would ever be created. In choosing the corporate form, neither party (or faction) would have invested in the enterprise if he had known or foreseen that the power of exclusive management would fall to the other or that his own participation would become distasteful. It is of special significance that the parties contemplated harmonious joint management after the manner of partners. It is, howevcr, this very desire which the choice of the corporate form, accompanied by a concommitant failure to recognize the greater inherent potential for usurpation of control, often makes vain. J. TiNGLE, supra note 26 , at 75 .

38. Hornstein, supra note 29 , at 236-37.

39. Sce note 11 supra and accompanying text.

40. Uniform Partnership Act $\$ 9(4)$; J. Crane, Partnership 275 (2d ed. 1952).

41. The Uniform Partnership Act was drafted and approved in 1914 by the Conference of Commissioners on Uniform State Laws. 6 UNIFORM LAwS ANN. 5 (1969). Since 1914, fortyfour jurisdictions have adopted the Act in substantially unmodified form. 6 UNIFORM LAws ANN. 5 (Supp. 1972).

42. Uniform Partnership ACt $\S 9(1)$ (West 1969).

43. Id. $\S 18(\mathrm{~h})$. 
ordinary scope of the partnership business? Is an explicit authorization by both partners a prerequisite to binding the firm; or may either partner, by his dissent, bar the proposed action?

Because of the relative ease with which a partnership can be dissolved, ${ }^{44}$ the issue posited above has been infrequently litigated ${ }^{45} \mathrm{~A}$ substantial majority of the cases which have dealt with the problem have held that a dissent by an equal partner terminates the statutory authority of a copartner as agent and forces the third party to rely solely on the credit of the partner dealing with him. ${ }^{46}$ Thus, in $D e$ Santis v. Miller Petroleum Co., ${ }^{47}$ a decision under the Uniform Partnership Act, the court held that an equal partner, having communicated to a supplier his refusal to be held liable for the purchase price of certain equipment ordered by his copartner, was not liable for any part of the purchase price even though the equipment was subsequently delivered and used solely for the benefit of the partnership. The rationale of the court focused on the communicated disclaimer of liability, equating the disclaimer with a bar to the copartner's authority to act for the partnership. Decisions preceding and following De Santis have uniformly required that the disclaimer be made by an equal partner or by a partner vested with veto powers and be communicated by the dissenting partner to the third party prior to the latter's injurious reliance upon the authority of the contracting partner ${ }^{48}$ In Summers v. Dooley, ${ }^{49}$ however, the Idaho Supreme Court recently ruled that an equal partner in a two-man partnership did not have authority, over the objection of his copartner, to hire a

44. See id. § 31 .

45. For a discussion of the cases which have examined the issue, see Note, The Permissible Conduct of a Partner in Carrying on the Firm Business, 20 CoLum. L. Rev. 66 (1929); 1960 DUKE L.J. 150.

46. De Santis v. Miller Petroleum Co., 29 Cal. App. 2d 679, 85 P.2d 489 (Dist. Ct. App. 1938); Leavitt v. Peck, 3 Conn. 124 (1819); Summers v. Dooley, 94 Idaho 87, 481 P.2d 318 (1971); Knox v. Buffington \& Co., 50 Iowa 320 (1879); Dawson Blakemore \& Co. v. Elrod, 105 Ky. 624, 49 S.W. 465 (1899); Bull v. Harris, 57 Ky. 195 (1857); Yeager v. Wallace, 57 Pa. 365 (1868); Bank of Bellbuckle v. Mason, 139 Tenn. 659, 202 S.W. 931 (1918). Some courts have reached the same results without relying on agency theory. St. Louis Brewing Ass'n v. Elmer, 189 Mo. App. 197, 175 S.W. 102 (1915) (since one partner has the power to dissolve the partnership by notice, thereby preventing the making of any further contracts in the firn's name, the dissident partner should also be able to protect himself by notice against particular contracts); Monroe v. Conner, $15 \mathrm{Me} .178$ (1838) (since a partner can bind the firm by his conduct, he should be able to terminate such liability by disclaimer).

47. 29 Cal. App. 2d 679, 85 P.2d 489 (Dist. Ct. App. 1938).

48. See cases cited note 46 supra.

49. 94 Idaho 87, 481 P.2d 318 (1971). 
new employee. Although the copartner's dissent was communicated solely to his partner and not to the employee, it was held sufficient, as between the partners, to prevent the contracting partner from charging the dissenting copartner with his share of the costs incurred as a result of the unilateral decision. Both De Santis and Summers support the assertion that authorization by less than a majority is no authorization at all. In National Biscuit Co. v. Stroud, ${ }^{50}$ a North Carolina decision applying the Uniform Partnership Act, the court interpreted the language of the statute somewhat differently than the courts in De Santis and Summers. The North Carolina court ruled that a dissenting copartner cannot avoid personal liability for the acts of his partner, even though the dissenter communicates his disclaimer to the third party. Reasoning that the Act required majority rule while simultaneously vesting each partner with equal management rights, the court held that the dissenting partner could not restrict his copartner's authority to act on matters within the ordinary scope of the partnership's business. In other words, prohibition by less than a majority is not an effective prohibition.

Writers who have dealt with even divisions in partnerships have almost uniformly accepted the view expounded in De Santis and Summers ${ }^{51}$ - that action by less than a majority cannot bind the partnership. In his treatise, Story takes the position that a disagreement among equal partners results in a "temporary suspension of the right of authority of each (partner) to carry on or manage the partnership business." ${ }^{52}$ The rationale for allowing disagreement to dictate removal of authority is that permitting each of the dissenting partners to continue to transact the firm's business might allow over-commitment of the partnership assets, for which dissolution is the only remedy. ${ }^{53}$

50. 249 N.C. 467,106 S.E.2d 692 (1959).

51. F. Burdick, Partnership 232-33 (3d ed. 1917); Crane, supra note 40, at 277-78; W. George, Partnership 159 (1897); E. Gilmore, Partnerships 368 (1911); N. Lindley, PartNership 403 (4th ed. 1881); IV. Shumaker, Partnership 172 (2d ed. 1912); J. Story, PartNERSHIP $\$ 123$ (7th ed. 1881).

52. Id. $\S 23$.

53. In cases of an even distribution of the partners as to whether or not an act within the scope of the business should be done, of which disagreement a third person has knowledge, it seems that logically no restriction can be placed upon the power to act. The partnership being a going concern, activities within the scope of the business should not be limited, save by the expressed will of the majority deciding a disputed question; half of the members are not a majority. In practical operation application of such a solution to projected transactions might be inconvenient and costly. If each of two persons wishes to buy goods, or hire employees to 


\section{CONCLUSION}

Corporate statutes which require majority rule to control corporate decisions but simultaneously allow voting arrangements which make that majority difficult to attain have enhanced the likelihood of close corporation deadlock. Until the legislatures undertake to amend the statutes, ${ }^{54}$ the burden is left with the judiciary to find a solution which logically comports with the parties' intentions at the time of corporate formation. Given the common features shared by the close corporations and the partnership, it may be that partnership theory provides the most hopeful direction for this pursuit.

While extension of partnership deadlock concepts to deadlocks arising in close corporations presents difficult theoretical problems, the courts have already deemed it expedient to apply partnership principles to close corporations. This extension has been accomplished by recognizing, in the officers of such entities, authority inherent in the mere possession of corporate office. ${ }^{55}$ The recognition of this authority, while consistent with the reality of the coalescence of ownership and management as well as the expectations of the parties, vests the officer of a close corporation with extraordinary authority; however, the other shareholder lacks the safeguards necessary to protect his investment in the enterprise. Though the corporate entity shields the individual shareholder from personal liability on corporate obligations, a mechanism is needed whereby a dissenting equal shareholder can protect his investment and livelihood by disclaiming the corporation's liability. It is suggested that this end could be achieved by allowing a shareholder who has bargained for equal control of the enterprise to disavow corporate liability by communicating to interested third partics his dissent to a particular act. Having recognized in the officers of close corporations the authority to bind the entity as if they had the power of general partners, the courts-at least in those states recognizing the effectiveness of a disclaimer ${ }^{56}$ - should be willing to extend to the dissident shareholder the same method of self-

an extent needed for the transaction of business, and if on disagreement known to third persons, each is to be considered as capable of acting, so as to bind the other, the firm may be put into the position of being disastrously overstocked with goods, services, or other things. In its praetical workings, the better rule appears to be that in case of even disagreement, known to third persons, no action new or positive can be taken until the partners themselves reach a solution. CRANE, supra note 40 , at $277-78$.

54. See note 11 supra and accompanying text.

55. See note 46 supra and accompanying text.

56. See notes 33-34 supra and accompanying text. 
protection that is enjoyed by a dissident partner.

The extension of the right to disclaim corporate liability has distinct advantages over the remedies recognized under traditional corporate principles. With the exception of the extraordinary remedies of injunction and mandamus, ${ }^{57}$ the corporate remedies require that the corporation actually be injured before the dissident shareholder can seek redress. Moreover, all of the corporate remedies require that the dissident shareholder take the initiative in bringing suit against the other shareholder. Consequently, it is the dissident, acting through a derivative action, ${ }^{58}$ who must bear the burden of blocking or redressing wrongs committed against the corporation. Assuming that the dissident shareholder can block the payment of corporate funds, ${ }^{59}$ the recognition of a right of disclaimer would shift the burden to the shareholder who favors an action which changes the status quo. If a shareholder acted in the face of a communicated dissent, he would have to prove his authority in a court proceeding for an accounting or for mandamus to require execution of corporate duties. Likewise, once the right to disclaim corporate liability is established,

57. A derivative action has some disadvantages. In New York, for example, the shareholder bringing suit on behalf of the corporation must meet the requirements of that state's securityfor-expense statute. N.Y. Bus. CoRP. LAw $\S 627$ (McKinney Supp. 1970). At least one state court has recognized the inequity of requiring an equal shareholder to bring his suit derivatively. Funk v. Spalding, 74 Ariz. 219, 246 P.2d 184 (1952) (a "partner" in a two-member "incorporated partnership" can maintain an action for an accounting in his own right, rather than rcquiring him to resort to a derivative action).

58. In the normal two-man or two-faction close corporation, the shareholders'agreement or the corporations' by-laws will provide that the corporate offices be divided among the shareholders: one will be President-Vice President while the other serves as SecretaryTrcasurer. Likewise, the agreement or by-laws will require that both officers sign checks or drafts drawn on the corporation. Such a provision would give the dissident shareholder "power of the purse" to block the outflow of corporate funds.

59. An argument could be made to allow a dissident shareholder to communicate an effective disclaimer to a third party even after a contract has been entered into between the third party and a corporation's officer acting beyond his authority. To allow a dissident shareholder power to disclaim corporate liability only when he learns of his "partner's" unauthorized actions prior to the execution of a contract may deprive the dissenting shareholder of effective relief. The shareholder favoring action could easily cireumvent the right of disclaimer by conducting the negotiations and exeeuting the contract in secret. Of course, the courts should be unwilling to allow a dissident sharcholder to protect his intcrest at the expense of an innocent third party, but the courts could serve the interests of both the dissident and the third party by fashioning a remedy which stops performance under the unauthorized contract while it gives the third party the "benefit of the bargain." Such a remedy would make the innocent third party whole and, at the same time, would limit the potential liability of the corporation. If allowed such a remedy, the dissident shareholder could protect the corporation from "being disastrously overstocked with goods, services or other things." See CRANE, supra note 40. 
third parties who have notice of a dissent must either refrain from transacting business with the corporation or act solely in reliance upon the individual credit of the contracting shareholder. ${ }^{00}$ Such a remedy should significantly diminish foreseeable harmony-disrupting litigation since, instead of a burden to block action resting on the shareholder who opposes action, a burden to justify affirmatively the authority to act will rest on the shareholder who favors action.

60. In several states, the legislatures have recognized the deadlock potential inhercnt in allowing high vote arrangements and have authorized their courts to exercise extraordinary powers in the event of deadlock. Some states authorize their courts to appoint a deadlockbreaking provisional director, see CAL. CORP. CODE $\$ 819$ (West 1955); VERNON's Mo. ANN. STAT. $\$ 351.323$ (1966). Other states provide for the appointment of a custodian, see DEL. Code ANN. tit. 8, § 226(b) (Supp. 1968); VA. CodE ANN. § 13.1-94 (Supp. 1968). Court ordered buy-out of dissenting shares at a price judicially determined to be fair is also provided in several states, see CAL. CoRP. Code $\$ 4658-59$ (West 1955); ConN. Gen. STAT. ANN. § 33384 (Supp. 1969); MD. ANN. Code art. 23, \& 109(c) (Supp. 1969); S.C. CodE ANN. \& 12-22.23 (Supp. 1969); W. VA. Code ANN. § 31-1-81 (1966). See Folk, supra note 27, at 954-56. 